\title{
DESTINATION MANAGEMENT ORGANIZATIONS: A SYSTEMATIZATION OF RECENT LITERATURE WITH A FOCUS ON NEW RESEARCH TRENDS
}

\author{
Adina Andra Triandafil ${ }^{1 *}$, Alexandra Cristina Dinu ${ }^{2}$, Florina Puie (Răzvanță) ${ }^{3}$, \\ Ana Șerbănescu ${ }^{4}$ \\ ${ }^{1}$ Bucharest University of Economic Studies, Marketing, Romania, adina.andra@gmail.com \\ ${ }^{2}$ Bucharest University of Economic Studies, Marketing, Romania, alexandracristina.dinu@mk.ase.ro \\ ${ }^{3}$ Bucharest University of Economic Studies, Business Administration, Romania, florina.puie@gmail.com \\ ${ }^{4}$ Bucharest University of Economic Studies, Business Administration, Romania, ana_serbanescu@hotmail.com
}

\begin{abstract}
Although the notion of destination management organization remains a particularly prolific and attractive concept, being extensively addressed in the last 20 years, there is no consensus at an academic level on how it can be operationalized. Much less empirically, little attempts have been developed in order to attain comprehensive ways of optimizing the activity of such organizations. The tendency for this concept to be associated with destination brand management is not necessarily representative, and by no means exhaustive. The present paper aims to highlight a series of definitions in this regard in the first part, following that in practice, to carry out a meta-analysis of recent literature, in order to identify the areas where Destination Management Organizations (DMOs) can be developed. Thus, we consider the exploration of different DMOs' analyses, within the Scopus (Elsevier) and Springer international databases which have published research in this regard in the past 2 years (2020-2021).
\end{abstract}

Keywords:

Destination management organizations; tourism brand management; DMOs meta-analysis

JEL Classification: Z32, C18, D20

DOI: $10.24818 / \mathrm{CTS} / 3 / 2021 / 2.06$

\section{Introduction}

The concept of destination management organization (DMO) is understood and applied from highly distinct perspectives, as a result of the definition provided by the World Tourism Organization (2004), whose features generally fall into one of the following categories: (a) National tourism authorities or organizations responsible for the management and marketing of tourism services at a national level; (b) regional or state DMOs responsible for the management and/ or marketing of tourism services in a geographical region defined for this purpose, sometimes, but not always, a local administrative or administrative region, such as a county, state or province; and (c) local DMOs responsible for the management and/ or marketing of tourism based on a smaller geographical area or a large city / town. Consequently, there is no standard followed by countries around the world.

Blain et al (2005) associate destination management organizations with destination branding, which is often reduced to logo branding. Hankinson (2004) highlights their potential with those of relational brand networks, emphasizing this last interactive component.

While some authors amplify the marketing component of the destination, others emphasize that of the destination itself (Borzyszkowski, 2015). The main plea of the management approach is that in the last 15 years, the DMOs have undergone a number of transformations, from typical marketing organizations, becoming entities with a comprehensive approach to tourism management (Presenza et al, 2005).

* contact author 
Gartrell, one of the first theorists to approach the entire activity of the DMOs in terms of their function and mandate, broadly defined their role in the sphere of commercializing the cities' image. Thus, in Gartrell's vision, the DMOs have the role of developing an image that positions cities in the tourism market as viable destinations for visitors. In addition, they must coordinate the different constituent elements of this process, each with a heterogeneous character, but requiring homogenization in order to build a unitary image (1988).

Within a historical approach of problematizing the evolution of the DMOs in Romania, Chaşovschi (2019) points out their relational component, mentioning that the first DMOs in our country had the role of mobilizing all stakeholders to develop local tourism and to promote tourist destinations. At the same time, however, citing the public positions highlighted by the Association for the Promotion and Development of Tourism in Braşov County, Chaşovschi highlights the need to avoid the mistakes of major destinations, as well as to assign public authorities a strategic, yet not exclusive role (2019).

\section{Methodology}

This paper aims to explore the different trends in the analysis of the concept of destination management organization, within the international academic journals that have published research in this regard in the last 2 years (2020-2021). Following the search, launched in May 2021, articles from fields other than tourism were excluded, as well as those published before 2020. The reason for this selection is the desire to exemplify the latest trends in tourism research. We applied a meta-analysis consisting of a mixed content analysis of the articles in the Scopus (Elsevier) and Springer databases, based on the keyword "destination management organizations". The articles are firstly processed qualitatively and grouped in cluster categories, which are then quantified at the entire level of the research area. The findings are to illustrate both how DMOs are understood in the recent literature and what aspects remain underaddressed in relation to these organizations.

\section{Results and discussion}

The studies dedicated exclusively to Destination Management Organizations were only 3: the study of Foris et al (2021) on optimizing the activity of the DMOs by using Lean management methods (alignment with all aspects of organizational culture, elimination of flows and resources useless); research conducted by Mrsic et al (2020), with a focus on the impact of new technologies in visualizing data related to tourists - in order to avoid the phenomenon of overcrowding in tourist destinations; and the analysis conducted by Huertas and Lalicic (2021) on the involvement of local DMOs on Facebook and Twitter platforms, illustrated by the analysis of their brand emotional communication strategies, user involvement metrics and their overall activity. These studies had the role of suggesting various strategies for more efficient resource management and higher capitalization of new technologies within DMOs.

All the other 98 articles that resulted from the search highlighted very different, scattered topics, and because the possibility of integrating them into sub-areas of interest in tourism was very limited, we proceeded to classifying them in 3 major strains of research, namely: research in the area of destination branding; studies in the field of destination marketing; and destination management analyses. The first category refers to studies that approach various aspects that can contribute to the creation of destination brands (online posting behavior, precise attributes in the offline communication of tourism organizations). The second category implies all studies that have explored the consumption behavior of tourists; achieving a certain loyalty to different destinations; various statistical models and latest generation technologies of tourist data visualization (urban areas, the movement of tourists to certain points of interest, sentiment analyses); and, in general, research aimed at achieving an efficient and sustainable tourism. 
Table no. 1: Exemplification of identified research in the field of destination marketing (excerpt)

\begin{tabular}{|c|c|}
\hline Citation & Studies' titles \\
\hline Schlesinger et al., 2020 & $\begin{array}{l}\text { Exploring the links between destination attributes, quality of service experience and } \\
\text { loyalty in emerging Mediterranean destinations }\end{array}$ \\
\hline $\begin{array}{l}\text { Ivars-Baidal et al, } \\
2021\end{array}$ & $\begin{array}{l}\text { Measuring the progress of smart destinations: The use of indicators as a management } \\
\text { tool }\end{array}$ \\
\hline Su et al., 2020 & $\begin{array}{l}\text { The link between travel motivation and satisfaction towards a heritage destination: } \\
\text { The role of visitor engagement, visitor experience and heritage destination image }\end{array}$ \\
\hline Tan and Lin, 2021 & Why do individuals word-of-mouth destinations they never visited? \\
\hline Tasci, 2020 & $\begin{array}{l}\text { Exploring the analytics for linking consumer-based brand equity (CBBE) and } \\
\text { financial-based brand equity (FBBE) of destination or place brands }\end{array}$ \\
\hline $\begin{array}{l}\text { Hernández-Mogollón } \\
\text { et al., } 2021\end{array}$ & $\begin{array}{l}\text { Integrating transactional and relationship marketing: a new approach to } \\
\text { understanding destination loyalty }\end{array}$ \\
\hline Tan \& Liou & $\begin{array}{l}\text { Analysis of the relationship between the perceived extent of a tourist destination and } \\
\text { smartphone use }\end{array}$ \\
\hline Cao et al., 2020 & TDIVis: visual analysis of tourism destination images \\
\hline Joseph et al, 2020 & $\begin{array}{l}\text { Pilgrim Satisfaction in a Mass Religious Gathering: Study from Sabarimala } \\
\text { Destination, Kerala State of India }\end{array}$ \\
\hline Armis et al., 2020] & $\begin{array}{l}\text { The attractiveness of a post-mining city as a tourist destination from the perspective } \\
\text { of visitors: a study of Sawahlunto old coal mining town in Indonesia }\end{array}$ \\
\hline Wu et al, 2021 & A group consensus-based travel destination evaluation method with online reviews \\
\hline Cortese et al, 2021 & $\begin{array}{l}\text { Knowledge sharing for coopetition in tourist destinations: the difficult path to the } \\
\text { network }\end{array}$ \\
\hline Fekih et al, 2020 & $\begin{array}{l}\text { A data-driven approach of origin-destination matrix construction from cellular } \\
\text { network signalling data: a case study of Lyon region (France) }\end{array}$ \\
\hline Li et al, 2021 & $\begin{array}{l}\text { Value proposition as a catalyst for innovative service experience: the case of smart- } \\
\text { tourism destinations }\end{array}$ \\
\hline Mohamadi et al., 2021 & $\begin{array}{l}\text { Conceptualizing sustainable-responsible tourism indicators: an interpretive } \\
\text { structural modeling approach }\end{array}$ \\
\hline $\begin{array}{l}\text { Rostami Nasab and } \\
\text { Shafahi, } 2021\end{array}$ & Estimation of origin-destination matrices using link counts and partial path data \\
\hline $\begin{array}{l}\text { Faghih-Imani and } \\
\text { Eluru, } 2020\end{array}$ & $\begin{array}{l}\text { A finite mixture modeling approach to examine New York City bicycle sharing } \\
\text { system (CitiBike) users' destination preferences }\end{array}$ \\
\hline $\begin{array}{l}\text { González-Rodríguez } \\
\text { and al, } 2020\end{array}$ & $\begin{array}{l}\text { The impact of virtual reality technology on tourists' experience: a textual data } \\
\text { analysis }\end{array}$ \\
\hline $\begin{array}{l}\text { Ishaq and Di Maria, } \\
2020\end{array}$ & $\begin{array}{l}\text { Sustainability countenance in brand equity: a critical review and future research } \\
\text { directions }\end{array}$ \\
\hline
\end{tabular}

Source: own research

The third category, that of research on destination management, includes analyses on the impact of tourism on destinations, from the perspective ecology and sustainability; and on managing the resources and challenges in these destinations.

Table no. 2: Exemplification of identified research in the field of destination management (excerpt)

\begin{tabular}{|l|l|}
\hline \multicolumn{1}{|c|}{ Citation } & \multicolumn{1}{c|}{ Studies' titles } \\
\hline Alola et al, 2021 & $\begin{array}{l}\text { Perspectives of globalization and tourism as drivers of ecological footprint in top } \\
\text { 10 destination economies }\end{array}$ \\
\hline Salman et al, 2021 & $\begin{array}{l}\text { Ecotourism development in Penang Hill: a multi-stakeholder perspective towards } \\
\text { achieving environmental sustainability }\end{array}$ \\
\hline $\begin{array}{l}\text { Fernández-Villarán et } \\
\text { al., 2021 }\end{array}$ & Model for measuring carrying capacity in inhabited tourism destinations \\
\hline Yoshikawa et al, 2021 & $\begin{array}{l}\text { An interdisciplinary study: disseminating information on dengue prevention and } \\
\text { control in the world-famous travel destination, Bali, Indonesia }\end{array}$ \\
\hline
\end{tabular}




\begin{tabular}{|c|c|}
\hline Citation & Studies' titles \\
\hline $\begin{array}{l}\text { Seraphin and Ivanov, } \\
2020\end{array}$ & Overtourism: a revenue management perspective \\
\hline Fethi and Senyucel & $\begin{array}{l}\text { The role of tourism development on } \mathrm{CO} 2 \text { emission reduction in an extended } \\
\text { version of the environmental Kuznets curve: evidence from top } 50 \text { tourist } \\
\text { destination countries }\end{array}$ \\
\hline Milićević et al, 2021 & $\begin{array}{l}\text { Sustainable tourism development in mountain areas in Šumadija and Western } \\
\text { Serbia }\end{array}$ \\
\hline Peterson, 2020 & $\begin{array}{l}\text { Over the Caribbean Top: Community Well-Being and Over-Tourism in Small } \\
\text { Island Tourism Economies }\end{array}$ \\
\hline $\begin{array}{l}\text { Hong and Frias- } \\
\text { Martinez, } 2020\end{array}$ & Modeling and predicting evacuation flows during hurricane Irma \\
\hline $\begin{array}{l}\text { Gonzáles-Mantilla and } \\
\text { León, } 2020\end{array}$ & $\begin{array}{l}\text { Tourism Management in South American Geological Areas: Comparing Two } \\
\text { Cases from Peru and Brazil }\end{array}$ \\
\hline Pourfaraj et al, 2020 & Conservation Management of Geotourism Attractions in Tourism Destinations \\
\hline Mandic, 2020 & $\begin{array}{l}\text { Structuring challenges of sustainable tourism development in protected natural } \\
\text { areas with driving force-pressure-state-impact-response (DPSIR) framework }\end{array}$ \\
\hline $\begin{array}{l}\text { Badar and Bahadure, } \\
2020\end{array}$ & Assessing tourism sustainability in hill towns: Case study of Shimla, India \\
\hline $\begin{array}{l}\text { Palacios-Florencio et } \\
\text { al, } 2021\end{array}$ & $\begin{array}{l}\text { Sustainable Tourism as a Driving force of the Tourism Industry in a Post-Covid-19 } \\
\text { Scenario }\end{array}$ \\
\hline Anup et al, 2020 & $\begin{array}{l}\text { Ecotourism and its impact on indigenous people and their local environment: case } \\
\text { of Ghalegaun and Golaghat of Nepal }\end{array}$ \\
\hline
\end{tabular}

Source: own research

Our research indicates that studies in the field of destination management and marketing (table no. 3 ) have been predominant, both totaling $87.13 \%$ of the selected sample of studies $(\mathrm{N}=101)$.

Table no. 3. Distribution of the identified domains in the selected studies, from the Springer and Scopus databases (2020-2021)

\begin{tabular}{|c|c|c|}
\hline Identified domain & $\begin{array}{c}\text { Number of identified articles } \\
\text { within the field }\end{array}$ & $\begin{array}{c}\text { Percentages of identified articles } \\
\text { within the field }\end{array}$ \\
\hline Destination branding & 13 & 12.87 \\
\hline Destination management & 36 & 35.64 \\
\hline Destination marketing & 52 & 51.49 \\
\hline
\end{tabular}

In the case of both areas of interest, there was an important trend towards the capitalization of new technologies for collecting data on consumers of tourism services $(30.7 \%, \mathrm{n}=52$; the rest being made up of very different categories and reduced in percentages each). For example, in a study dedicated to images of tourist destinations (integrated into the marketing category of destinations), Cao and $\mathrm{Li} \mathrm{(2020)}$ have analyzed the content generated by tourism users (CGU) - meaning feedback from tourism sites and which provides important information for building a destination image. The paper proposes a thoroughly designed visual analysis system, in order to obtain a relatively comprehensive destination image. Specifically, a keyword-based sentiment visualization method is proposed to associate the cognitive image with the emotional image and to provide a dynamic visual coding interaction method for the multi-attribute characteristics of the sequences. The efficacy and degree of use of TDIVs are demonstrated by four cases and a user study. Hernández- Mogollón et al. (2021) propose a study model of the factors that generate loyalty to the destination - applied specifically to rural tourism - and thus seeks to enrich the transactional marketing perspective (image, quality and value) with an emphasis on the relational component (trust, attachment and satisfaction). The integration of transactional and relational submodels are explored as antecedents of overall satisfaction and destination loyalty. The results are based on an online survey applied to 464 rural tourists. The data were analyzed using the least squares technique, highlighting that transactional models need to be enriched with variables such as trust and attachment. Fekih et al (2020) propose a methodology for estimating origin-destination 
matrices based on passively collected data, for signaling the cellular network of millions of anonymous mobile phone users in the Rhône-Alpes region, France. Unlike call details recording data that is based solely on phone usage, signaling data includes all network-based recordings, which provide greater spatial granularity. The explored dataset, which consisted of time-stamped traces from $2 \mathrm{G}$ and $3 \mathrm{G}$ cellular networks with unique user identifiers and cell tower locations, is used to first analyze each user's mobile phone activity indicators to qualify the mobility information involved in these records. These indicators serve as criteria to identify users whose device data transmission systems are sufficiently well distributed over the analyzed period to allow the study of their mobility. The trips were then extracted from the spatio-temporal traces of the users for whom the home location could be detected and were derived based on a minimum stationary time assumption that allows the determination of the activity areas (stop) for each user.

Within the research dedicated to destination management, beyond the use of new technologies, different models for estimating the sustainability of local tourism had an important proportion, as well as the efforts of local authorities, in some cases, to create this sustainability. A dominant concern here is the development of ecotourism, amid awareness of the impact of global tourism on the environment $(13.88 \%, \mathrm{n}=36$; the rest of the articles in this category with heterogeneous approaches, totally different in terms of analysis).

In the field of destination branding, we have various case studies that highlight the positioning of tourism brands in local and international markets.

Thus, in the very recent literature, studies focused exclusively on the DMOs are very few within the analyzed databases $(3.96 \%, \mathrm{~N}=101)$ but, based on tourism studies illustrated here which show an increased interest in destination marketing and management, we can estimate that the attention of the academic community will also consider the capitalization of new technologies within the Destination Management Organizations; as well as the same concern for the sustainability of tourism.

The results of this meta-analysis confirm Borzyszkowski's argument that there is a tendency to emphasize the destination marketing component in the literature, while other studies value the management of destinations (2005). At the same time, these results are convergent with those Negruşa and Coroş (2016), indicating identical patterns in the ranking of the 3 identified areas (branding, management and marketing of destinations) and the exponentially lower number of studies in regards to the DMOs. Thus, although there is a trend of internationalization of tourism organizations as a result of globalization, there is no focus towards the research of Destination Management Organizations, despite the high potential for promotion and management of these institutions. If we also take into account the fact that there is no consensus in the state legislatures on the conditions that an organization must meet to be considered a DMO, we can conclude that these entities fail to position themselves as a priority both on the political and academic agenda.

At the same time, if we consider the fact that on a global scale, some DMOs are struggling with financing issues, others are dealing with organizational and infrastructural necesities (Girma, 2020 in press), much research is needed to understand the challenges these entities are facing nowadays and how to address them within each cultural background.

\section{Conclusions}

The findings of this research indicate, first of all, that DMOs are, paradoxically, under-researched withing the broader field of destination management, with only 3 articles approaching their existence and only 1 of these pointing to a sustainable paradigms for their development. In addition, the field of destination management organization tends to be understood largely in terms of of its marketing component and destination attributes, especially in the light of new technologies, and much less in relation to DMOs.

This reduced academic visibility, as well as lacking constant presence on the public agenda, contrasts with the needs and potential of DMOs worldwide. Although DMOs have the proven capacity to be 
engines of economic development, many have dealt with serious sustainability and organizational issues, which fail to be acknowledged.

Further research is needed, thus, to explore the barriers and challenges of DMOs which are impeding them to become fully profitable, agenda-worthy entities, in their own cultural setting. That way, we would gain a more nuanced and authentic perspective over the broader field, as well.

\section{References}

Alola, A. A., Eluwole, K. K., Lasisi, T. T. and Alola, U. V., 2021. Perspectives of globalization and tourism as drivers of ecological footprint in top 10 destination economies. Environmental Science and Pollution Research, 28, pp. 31607-31617.

Anup, K, C., Ghimire, S., \& Dhakal, A., 2020. Ecotourism and its impact on indigenous people and their local environment: case of Ghalegaun and Golaghat of Nepal. GeoJournal, 1-19. Available at https://doi.org/10.1007/s10708-020-10222-3.

Armis, R. and Kanegae, H., 2019. The attractiveness of a post-mining city as a tourist destination from the perspective of visitors: a study of Sawahlunto old coal mining town in Indonesia. Asia-Pacific Journal of Regional Science, 4(2), pp. 443-461.

Badar, R. N. and Bahadure, S. P., 2020. Assessing tourism sustainability in hill towns: Case study of Shimla. India Journal of Mountain Science, 17(9), pp. 2241-2261.

Baidal, J., Celdrán Bernabeu, M. A., Femenia-Serra, F., and Giner, D.. 2020. Measuring the progress of smart destinations: the use of indicators as a management tool. Journal of Destination Marketing \& Management, 19, 100531, pp. 1-19.

Blain, C., Levy, S. E. and Ritchie, J. R. B., 2005. Destination Branding: Insights and Practices from Destination Management Organizations. Journal of Travel Research, 43(4), pp. 328-338.

Borzyszkowski, J., 2005. The past, present and future of destination management organizations (DMO)- The example of national tourism organizations (NTO). In Proceedings of the 9th International management conference "Management and Innovation For Competitive Advantage", November 5th-6th, 2015, Bucureşti, pp. 56-66.

Cao, M.-q. Liang, J., Li, M.-z., Zhou, Z.-h. and Zhu, M., 2020. TDIVis: visual analysis of tourism destination images. Frontiers of Information Technology \& Electronic Engineering, 21, pp. 536-557.

Chaşovschi, C., 2019. The Evolution of Destination Management Organisations (DMOs) in Romania. The USV Annals of Economics and Public Administration, 19(2), pp. 15-24.

Cortese, D., Giacosa, E. \& Cantino, V., 2021. Knowledge sharing for coopetition in tourist destinations: the difficult path to the network. Revue of Managerial Science, 15, pp. 275-286.

Faghih-Imani, A. and Eluru, N., 2020. A finite mixture modeling approach to examine New York City bicycle sharing system (CitiBike) users' destination preferences. Transportation, 47, pp. 529-553.

Fekih, M., Bellemans, T., Smoreda, Z., Bonnel, P., Furno, A. \& Galland, S., 2020. A data-driven approach for origin-destination matrix construction from cellular network signalling data: a case study of Lyon region (France). Transportation. Available at https://doi.org/10.1007/s11116-020-10108-w.

Fernández-Villarán, A., Espinosa, N., Abad, M. and Goytia, A., 2020. Model for measuring carrying capacity in inhabited tourism destinations. Portuguese Economic Journal, 19, pp. 213-241.

Fethi, S. and Senyucel, E., 2021. The role of tourism development on CO2 emission reduction in an extended version of the environmental Kuznets curve: evidence from top 50 tourist destination countries. Environment, Development and Sustainability, 23(7), pp. 1499-1524.

Gartrell, R. B., 1988. Destination marketing for convention and visitor bureaus. Dubuque, Iowa:Kendall/Hunt Publishing Company.

Girma, L. L. G., 2020. A Funding Crisis at Destinations Spurs New Tourism Marketing Models. Skift, https://skift.com/2020/12/01/funding-crisis-facing-destinations-forces-rethinking-for-tourismmarketing/ 
Gonzáles-Mantilla, P. G., León, C. J., 2020. Tourism Management in South American Geological Areas: Comparing Two Cases from Peru and Brazil. Geoheritage, 12(2). Available at https://doi.org/10.1007/s12371-020-00455-6.

González-Rodríguez, M., Díaz-Fernández, M. C. and Pino-Mejías, M., 2020. The impact of virtual reality technology on tourists' experience: a textual data analysis. Soft Computing, 24, pp. 13879-13892.

Hankinson, G., 2004. The brand images of tourism destinations: A study of the saliency of organic images. Journal of Product \& Brand Management, 13, pp. 6-14.

Hernández-Mogollón, J. M., Alves, H., Campón-Cerro, A. M. and Di-Clemente, E., 2021. Integrating transactional and relationship marketing: a new approach to understanding destination loyalty. International Review on Public and Nonprofit Marketing, vol. 18(1), pp. 3-26.

Hong, L. and Frias-Martinez, V., 2020. Modeling and predicting evacuation flows during hurricane Irma. EPJ Data Science, 9(1): 29

Ishaq, M. I. and Di Maria, E., 2020. Sustainability countenance in brand equity: a critical review and future research directions. Journal of Brand Management, 27, pp.15-34.

Joseph, J. K., Ambady, K. G., Dev, K. A., Hsu, E. B. and Pradeepkumar, A. P. (2020). Pilgrim Satisfaction in a Mass Religious Gathering: Study from Sabarimala Destination, Kerala State of India. Journal of religion and health, 59(4), pp. 1713-1727.

Li, C.-Y., Fang, Y.-H. and Sukoco, B. M., 2021.Value proposition as a catalyst for innovative service experience: the case of smart-tourism destinations. Service Business, 15(2), pp. 281-308.

Mandić, A., 2020. Structuring challenges of sustainable tourism development in protected natural areas with driving force-pressure-state-impact-response (DPSIR) framework. Environment Systems and Decisions, 40 , pp. 560-576.

Milićević, S., Bošković, N. and Lakićević, M., 2021. Sustainable tourism development in mountain areas in Šumadija and Western Serbia. Journal of Mountain Science, 18, pp. 735 - 748.

Mohamadi, S., Abbasi, A., Kordshouli, H. A. R. and Askarifar, K., 2021. Conceptualizing sustainable- responsible tourism indicators: an interpretive structural modeling approach. Environment, Development and Sustainability. Available at https://doi.org/10.1007/s10668-021-01442-9.

Negrușa, A. L. and Coroș, M. M., 2016. Destination Management Organizations' (DMOs) Roles and Performances - Literature Review. The 2nd International Scientific Conference SAMRO, pp. 267-274.

Palacios-Florencio, B., Santos-Roldán, L., Berbel-Pineda, J. M. and Castillo-Canalejo, A. M. (2021). Sustainable Tourism as a Driving force of the Tourism Industry in a Post-Covid-19 Scenario. Social Indicators Research. Available at https://doi.org/10.1007/s11205-021-02735-2.

Peterson, R.R., 2020. Over the Caribbean Top: Community Well-Being and Over-Tourism in Small Island Tourism Economies. International Journal of Community Well-Being, 1-38.

Pourfaraj, A., Ghaderi, E., Jomehpour, M. and Ferdowsi, S., 2020. Conservation Management of Geotourism Attractions in Tourism Destinations. Geoheritage, 12(4): 80. Available at https://doi.org/10.1007/s12371020-00500-4.

Presenza, A., Sheehan, L. and Ritchie, J. R.B. (2005). Towards a Model of the Roles and Activities of Destination Management Organizations. Journal of Hospitality, Tourism and Leisure Science. 3(1), pp. 1-16.

Rostami Nasab, M. and Shafahi, Y., 2021. Estimation of origin-destination matrices using link counts and partial path data. Transportation, 47, pp. 2923-2950 (2020).

Salman, A., Jaafar, M., Mohamad, D. and Malik, S., 2021. Ecotourism development in Penang Hill: a multistakeholder perspective towards achieving environmental sustainability. Environmental science and pollution research international, 1-14. Advance online publication, https://doi.org/10.1007/s11356-02113609-y.

Schlesinger, W., Cervera-Taulet, A. and Pérez-Cabañero, C., 2020. Exploring the links between destination attributes, quality of service experience and loyalty in emerging Mediterranean destinations. Tourism Management Perspectives, 35, 100699, pp. 1-10.

Seraphin, H. and Ivanov, S., 2020. Overtourism: a revenue management perspective. Journal of Revenue and Pricing Management, 19, pp. 1-5. 
Su, D., Nguyen, N., Nguyen, Q. and Tran, T., 2020. The link between travel motivation and satisfaction towards a heritage destination: The role of visitor engagement, visitor experience and heritage destination image. Tourism Management Perspectives, 34.

Tan, W. K. and Lin, C. H., 2021. Why do individuals word-of-mouth destinations they never visited? Service Business, 15, pp. 131-149.

Tan, W.- K. and Liou, P.- H., 2020. Analysis of the relationship between the perceived extent of a tourist destination and smartphone use, Service Business, vol. 14(2), pp. 263-285.

Tasci, A., 2020. Exploring the analytics for linking consumer-based brand equity (CBBE) and financial-based brand equity (FBBE) of destination or place. Place Branding and Public Diplomacy, 16, pp. 36-59.

World Tourism Organization, 2004. Survey of destination management organisations. Madrid, Spain: World Tourism Organization.

Wu, J., Hong, Q., Cao, M., Liu, Y. and Fujita, H. (2021). A group consensus-based travel destination evaluation method with online reviews. Applied Intelligence. Available at https://doi.org/10.1007/s10489-02102410-6.

Yoshikawa, M.J., Kusriastuti, R. and Liew, C., 2020.An interdisciplinary study: disseminating information on dengue prevention and control in the world-famous travel destination, Bali, Indonesia. Evolutionary and Institutional Economics Review, 17, pp. 265-293. 